\title{
HVAC RENDSZER MODELL ALAPÚ PREDIKTÍV SZABÁLYOZÁSA
}

\section{MODEL-BASED PREDICTIVE CONTROL OF AN HVAC SYSTEM}

\author{
Kardos Tamás ${ }^{1}$, Kutasi Dénes Nimród ${ }^{2}$ \\ ${ }^{1}$ Kolozsvári Műszaki Egyetem, Automatika és Számítástechnika Kar, Automatizálás Tanszék. Kolozsvár, \\ Románia, kardos_tamas2007@yahoo.com. \\ ${ }^{2}$ Sapientia Erdélyi Magyar Tudományegyetem, Marosvásárhelyi Kar, Villamosmérnöki Tanszék. Marosvá- \\ sárhely, Románia, kutasi@ms.sapientia.ro
}

\begin{abstract}
This paper presents the application of two, model-based predictive control (MPC) algorithms on the cooling system of an office building. The two strategies discussed are a simple MPC, and an adaptive MPC algorithm connected to a model predictor. The cooling method used represents the air-conditioning unit of an HVAC system. The temperature of the building's three rooms is controlled with fan coil units, based on the reference temperature and with different constraints applied. Furthermore, the building model is affected by dynamically changing interior and exterior heat sources, which we introduced into the controller as disturbances.
\end{abstract}

Keywords: control, cooling, MPC, prediction, constraint.

\section{Összefoglalás}

A cikkben bemutatásra kerül két, modell alapú prediktív szabályozó (MPC) algoritmus, melyek egy irodaépület hőmérsékletét szabályozzák. Előbb ismertetve van a klasszikus MPC, majd egy modell becslővel összekötött, adaptív MPC, külön kiemelve a fejlesztési folyamatot. Az alkalmazott hütés-technika egy HVAC rendszer légkondicionáló részét képezi. Az épület három szobájának hőmérsékletét hűtőkonvektorok vezérlésével állítjuk a megadott referencia hőmérséklet szerint, különböző megszorításokat figyelembe véve. Az épületmodellre hatással vannak dinamikusan változó külső és belső hőforrások is, amelyeket a szabályozóban zajként kezeltünk.

Kulcsszavak: szabályozás, hütés, MPC, predikció, megszorítás.

\section{Bevezetés}

A HVAC rendszerek magukba foglalják a fütésért, szellőztetésért és légkondicionálásért felelős épületgépészeti berendezéseket. Ilyen rendszereket elsősorban irodaépületekben, áruházakban használnak, de esetenként lakásokban is előfordulhatnak. Mivel az említett épületek energiafelhasználásának nagy részét fütő- és hűtőberendezések működtetése képezi, különös fontossággal bír egy optimális és hatékony szabályozó algoritmus kidolgozása, alkalmazása.

A szakirodalomban számos cikk foglalkozik hasonló rendszerek szabályozásával: -hibrid modell alapú prediktív szabályozó lakó-épületre történő alkalmazását írják le az [1]-ben;

-Fuzzy neurális hálózatokat és genetikus algoritmust alkalmazó MPC szabályozót hasonlítanak össze a [2]-ben;

-PID, illetve robusztus PID kerül bemutatásra a [3] és [4]-ben;

- az [5] Fuzzy szabályozót ötvöz PID tulajdonságokkal.

A tanulmányban szereplő rendszer egy HVAC berendezés légkondicionáló részével foglalkozik. A szabályozott bemenetek a hűtőközeg hőmérséklete $\left(\mathrm{T}_{\mathrm{s}}\right)$ és a ventilátoros konvektorok vezér- 
lőjelei $\left(\mathrm{FS}_{1}, \mathrm{FS}_{2}\right.$ és $\left.\mathrm{FS}_{3}\right)$. A szobák hőmérsékletére hatással van a konvektorok által generált hütött levegőn kívül a külső levegő hőmérséklete, a napsugárzás, illetve egyéb hőforrások, mint például emberek jelenléte vagy gépek müködtetése. Ezen tényezők bizonytalan predikciók formájában szerepelnek a rendszerben. A kapott modell elvi rajza az 1 . ábrán látható.

A dolgozat célja különböző - az említett hűtőrendszer szabályozására szolgáló - modell alapú prediktív szabályozók tanulmányozása.

Szerkezetileg a dolgozat a következő módon van felépítve. A 2. fejezetben a szabályozott rendszer modellje van bemutatva állapotteres formában, részletezve a rendszer különböző bemeneteit és kimeneteit, továbbá szemléltetve van a rendszer válasza nyílt hurkú szimuláció esetén. A 3. fejezet első alfejezete a modell alapú prediktív szabályozás elméleti hátterét írja le, a második alfejezet ennek a rendszerrel való összekötését, alkalmazását ismerteti, míg a harmadik alfejezet egy adaptív modell alapú prediktív szabályozó tervezését részletezi. Mindezek után a 4. fejezet a következtetéseket taglalja.

\section{Szabályozott rendszer}

A modellezett irodaépület három déli fekvésű szobából áll, amelyek egy-egy hütőkonvektorral vannak felszerelve. Az épület dinamikája állapotteres modellel írható le az (1)-es képlet alapján

$$
\begin{aligned}
& \dot{x}=A x+B u \\
& y=C x+D u
\end{aligned}
$$

ahol az $x$ állapotvektor a három szoba $T_{a}$ levegőés $T_{\text {fal }}$ falhőmérsékletéből tevődik össze.

$$
x=\left[\begin{array}{llllll}
T_{\mathrm{a} 1} & T_{\mathrm{a} 2} & T_{\mathrm{a} 3} & T_{\text {fal 1 }} & T_{\text {fal 2 }} & T_{\text {fal 3 }}
\end{array}\right]^{T}
$$

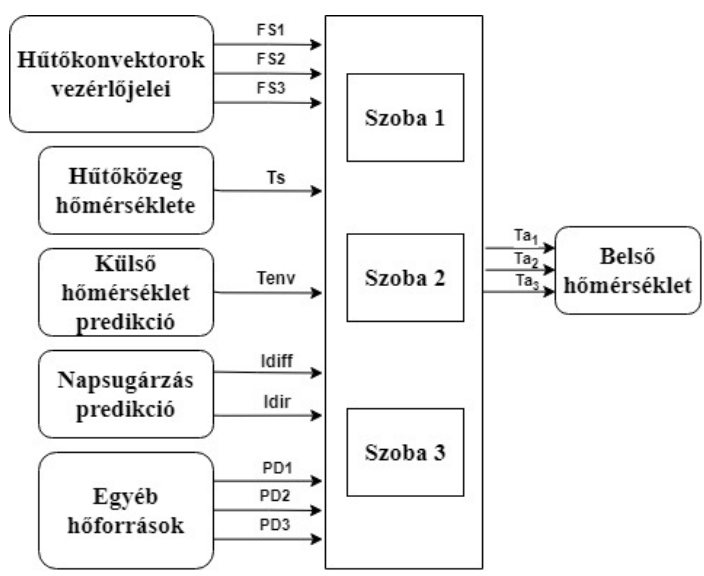

1. ábra. Rendszer elvi rajza
A bemeneti $u$ vektort a $T_{e n v}$ külső levegőhőmérséklet, $I_{d i r}$ közvetlen napsugárzás, $I_{\text {diff }}$ közvetett napsugárzás, a ventilátorok által leadott $P_{F C U}$ hö, illetve $P_{D}$ egyéb hőforrások alkotják.

$u=\left[\begin{array}{lllllllll}T_{e w} & I_{\text {dir }} & I_{d i f f} & P_{F C U, 1} & P_{F C U, 2} & P_{F C U, 3} & P_{D, 1} & P_{D, 2} & P_{D, 3}\end{array}\right]^{7}$

A $T_{e n v} I_{d i r}$ és $I_{d i f f}$ bemeneti tényezők a predikciós értékek és a normális eloszlással modellezett predikciós hibák összegével egyenlőek. A $P_{D}$-vel jelölt egyéb hőforrások ugyancsak normális eloszlással írhatók le az alábbi képlet alapján:

$$
P_{D, i}=\left\{\begin{array}{ccc}
k_{i}+w_{D, i} & \text { ha } & 8: 00 \leq h \leq 18: 00 \\
w_{D, i} & \text { másként }
\end{array}\right.
$$

Ezen hőforrások esetén figyelembe van véve a munkaidőben jelentkező nagyobb intenzitású hő, amely $k_{i}$-vel van jelölve és szobánként az (5) szerint változik.

$$
k_{i}=\left\{\begin{array}{lll}
100 & \text { ha } & i=1 \\
120 & \text { ha } & i=2 \\
150 & \text { ha } & i=3
\end{array}\right.
$$

Az y kimeneti vektor a szobahőmérsékletekből áll:

$$
y=\left[\begin{array}{lll}
T_{a, 1} & T_{a, 2} & T_{a, 3}
\end{array}\right]^{T}
$$

A hűtőkonvektorokon átvezetett hűtőközeg hőmérséklete ugyancsak szabályozható változó, mely $T_{s} \in[7,11]$ közötti értékeket vehet fel.

A szabályozó algoritmus fejlesztésére különböző predikciós vektorok álltak rendelkezésre. A külső levegőhőmérsékletről, illetve a közvetlen és közvetett napsugárzásról óránként változó értékek voltak meghatározva 24 órás periódusra. Az elektromos energia áráról azonos periódusra 15 percenként változó értékek voltak szolgáltatva.

A rendszer teljesítménye leírható egy euróban számolt működési költséggel, amely az elhasznált elektromos energia ára, az előírt hőmérséklettől való eltérés és a hűtéssel keletkezett zaj összegével egyenlő.

A szabályozott rendszerről további információk a [6]-ban és [7]-ben találhatóak.

A rendszer dinamikájának tanulmányozása érdekében nyílt hurkú szimulációt futtattunk. A szimuláció időtartama 2 nap volt, ami alatt a hütőközeg hőmérsékletét $9^{\circ} \mathrm{C}$ fokra állítottuk. A konvektorokat mindkét nap esetén reggel 8 és este 8 óra között bekapcsoltuk, ezen kívül kikapcsolt állapotban tartottuk őket.

A 3. ábrán látható a 3 szoba levegőhőmérsékleteinek változása eltérő színekkel, amelyek megfelelő szabályozás nélkül 14 és 27 Celsius fok kö- 
zött mozognak. A 2. ábrát figyelve észrevehető a hütőkonvektorok állapotának hatása: bekapcsolt állapotban nagymértékben csökken, kikapcsolva pedig a külső tényezők alapján változik a belső hőmérséklet. Ezt szemlélteti a 4. ábra, amely a napsugárzás hatását mutatja. Megfigyelhető, hogy a magas értékekkel egyidejüleg a szobahőmérséklet ugrásszerűen megnő. Ezzel ellentétben a külső hőmérséklet változása alig befolyásolja a szobák hőmérsékletét.

\section{Tervezett szabályozó}

\subsection{Elméleti háttér}

A modell alapú prediktív szabályozás (MPC) egy elterjedt irányítási módszer olyan szabályozási feladatok esetén, ahol a szabályozott rendszer matematikai modellje ismert, illetve a cél egy horizonttól függő, korlátos optimum-keresés megoldása. Véges, csúszó horizontú irányítás esetén egy négyzetes célfüggvény minimumát teljesítő optimális szabályozó jelet keresünk:

$$
\begin{aligned}
& J\left(\underline{x}_{k}, \underline{u}\right)=\underline{e}_{k+N}^{T} \cdot F \cdot \underline{e}_{k+N}+\ldots \\
& +\sum_{i=0}^{N-1} \underline{e}_{k+i}^{T} \cdot Q_{k+i} \cdot \underline{e}_{k+i}+\sum_{i=0}^{N_{c}-1} \Delta \underline{u}_{k+i}^{T} \cdot R_{k+i} \cdot \Delta \underline{u}_{k+i}
\end{aligned}
$$

ahol $e_{k+i}$ a követési hibát, $\Delta u_{k+i}=u_{k+i}-u_{k+i-1}$ a vezérlőjel változását, $\mathrm{N}$ a predikciós horizontot, $\mathrm{Nc}$ pedig a szabályozási horizontot jelöli. Q és F a pozitív szemidefinit súlyzómátrixok, illetve $\mathrm{R}$ a pozitív súlyzómátrix. Csúszó horizont során a kiszámított optimális szabályozási jelszekvencia első elemét használjuk fel. A szekvencia többi részét elvetjük, mivel a következő mintavételben újra lesznek számolva [8].

\subsection{Klasszikus MPC alkalmazása}

Első lépésként egy állapotteres, modell alapú, véges, mozgó horizontú, optimális szabályozó (MPC) algoritmussal próbáltuk a rendszert szabályozni, ennek érdekében a Simulinkben adott MPC Controller blokkot illesztettem a modellbe. $\mathrm{Az}$ algoritmus működéséhez elsősorban szükség van egy mpc objektumra, amely tartalmazza a szabályozó tulajdonságait és meghatározza a müködését. Ezen objektum létrehozására használhatjuk az MPC Designer eszközt, megszabva a blokk bemeneteit, illetve kimeneteit:

- vezérelt változók: hűtőkonvektorok vezérlőjelei; - mérhető zajok: aktuális külső hőmérséklet, közvetlen és közvetett napsugárzás, egyéb hőforrások és a hütőközeg hőmérséklete;

-nem mérhető zajok: 0;
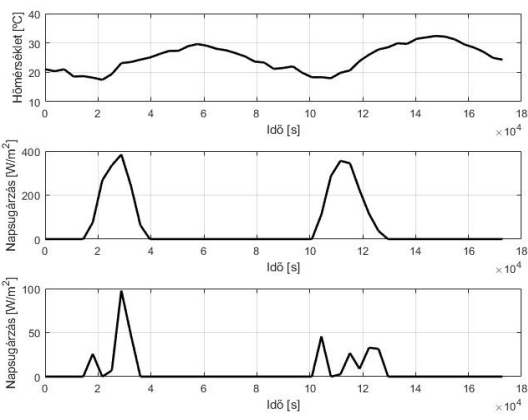

2. ábra. Hütőkonvektorok vezérlőjelei

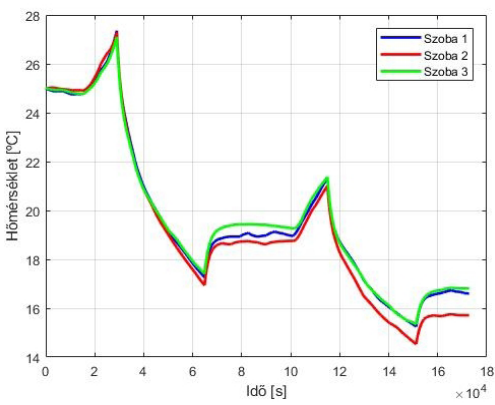

3. ábra. Szobák hőmérséklete

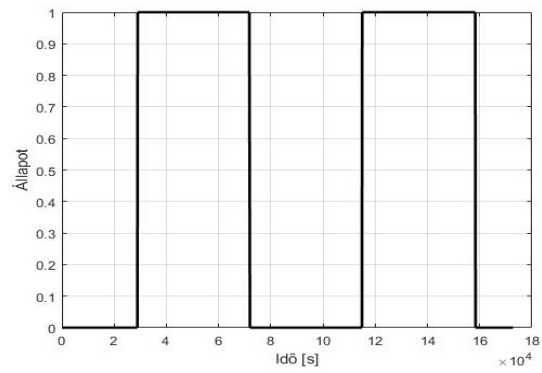

4. ábra. Külső hömérséklet, közvetlen napsugárzás, közvetett napsugárzás

- mérhető kimenetek: szobák aktuális hőmérséklete; -nem mérhető kimenetek: 0.

Ezt követően beállítjuk a szabályozó minta-vételezési idejét 1 mp-re, majd a könnyebb szabályozás céljából a hűtőközeg hőmérsékletét konstans módon 8 fokosnak tekintjük. Mivel a szabályozó működéséhez lineáris rendszerre van szükség, de a tanulmányozott rendszer nem teljesíti ezt a kritériumot, linearizálni kellett a modellt. Erre egy lehetséges módszer egy stabil munkapont keresése, amely körül elvégezhető a linearizálás. A munkapont megkeresésére az operpoint függvényt használtam.

A szabályozott rendszer úgy van felépítve, hogy a hűtőkonvektorokra kiadott vezérlőjel értéke 0 vagy 1 között váltakozik, tehát boolean típusú. Továbbá, az említett vezérlőjel felhasználásával lesz 
kiszámítva a levegőáramlat erőssége és a pumpák teljesítménye. Linearizálás során az első három mintavételt követően a hűtőkonvektorra a megengedettnél nagyobb értékű vezérlőjel került. Ez hibát vezetett be a rendszerbe, aminek kiküszöbölésére linearizálás alatt az említett számításokat konstans értékekkel helyettesítettük. A rendszer helyes működéséhez ezután visszaállítottuk az eredeti számítási függvényeket.

A meglévő lineáris rendszerrel a következő lépés a szabályozó teljesítményének, erősségének hangolása lett volna, azonban ez nem volt lehetséges, mivel a szabályozó nem működött helyesen: végig null-mátrixokat kaptunk vezérlőjelként. Az okok tanulmányozása során arra a következtetésre jutottunk, hogy a szabályozott rendszerünk túl komplex ahhoz, hogy klasszikus MPC-vel szabályozható legyen.

\subsection{Adaptív MPC modell becslóvel}

Következő lépésként egy adaptív MPC szabályozót alkalmazását tanulmányoztuk, online lineáris modell becslővel összekötve. A rendszer kimenetei és bemenetei alapján Kálmán szürőt használtunk egy ARX regressziós modell becslésére (8), mely egy lineáris modellt eredményezett.

$$
\begin{aligned}
& y(t)+A_{1} \cdot y(t-1)+A_{2} \cdot y(t-2)+\ldots+A_{n a} \cdot y(t-n a)= \\
& B_{0} \cdot u(t)+B_{1} \cdot u(t-1)+\ldots+B_{n b} \cdot u(t-n b)+e(t)
\end{aligned}
$$

ahol $\mathrm{A}(\mathrm{t})$ rendszer mátrix, $\mathrm{B}(\mathrm{t})$ bemeneti mátrix, $\mathrm{y}(\mathrm{t})$ a kimenet, $\mathrm{u}(\mathrm{t})$ a bemenet és e(t) fehér zaj.

Ezután ARX-SS transzformációval a becsült modellt állapotteres formába hoztuk. Az adaptív MPC ezt a becsült modellt, a referenciát és a rendszer modell kimeneteit felhasználva becsülte meg az új állapotokat, illetve határozta meg a vezérlőjeleket. A szabályozó hurok elvi rajza az 5 . ábrán látható.

\section{Következtetések}

A dolgozatban egy irodaépület hőmérsékletének szabályozására alkalmas prediktív módszereket ismertettünk. Tanulmányoztuk a klasszikus MPC alkalmazását, amely a modell hibrid jellege, tehát a kapcsoló típusú kimenet miatt sikertelen volt. Ezt követően felvázoltuk egy adaptív MPC kidolgozását és az ehhez szükséges lineáris modell becslését. A további tervek között szerepel az említett módszer alkalmazása a tanulmányozott rendszerre.

\section{Köszönetnyilvánítás}

A kutatást Magyarország Collegium Talentum 2018 programja támogatta.

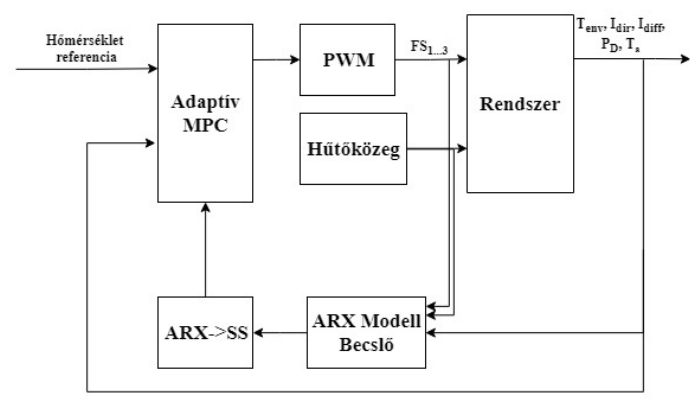

5. ábra. A szabályozott rendszer elvi rajza

\section{Szakirodalmi hivatkozások}

[1] Massimo F., Josh W., Zhenjun M., Julio H. B., Paul C.: Hybrid model predictive control of a residential HVAC system with on-site thermal energy generation and storage. Applied Energy, 187. (2017) 465-479.

https://doi.org/10.1016/j.apenergy.2016.11.041

[2] Zhang F.: Building Temperature Control with Intelligent Methods. Electronic Theses and Dissertations, 733 (2014).

https://digitalcommons.du.edu/etd/733

[3] Tashtoush B., Molhim M., Al-Rousan M.: Dynamic model of an HVAC system for control analysis. Energy, 30/10. (2005) 1729-1745.

https://doi.org/10.1016/j.energy.2004.10.004

[4] Kasahara M., Matsuba T., Kuzuu Y., Yamazki T., Hashimoto Y., Kamimura K., Kurosu S.: Design and Tuning of Robust PID Controller for HVAC Systems. ASHRAE Transactions, 105/2. (1999) 154-166.

https://www.researchgate.net/publication/236447627_Design_and_tuning_of_robust_ PID_controller_for_HVAC_systems

[5] Huan S., Nelson R.M.: A PID-Law-Combining Fuzzy Controller for HVAC Applications. ASHRAE Transactions, 97/2. (1991) 768-774.

[6] Kardos T., Kutasi D. N.: HVAC rendszer modellezése és modell alapú irányítása. In: A XIX. Müszaki Tudományos Ülésszak, Kolozsvár, Románia, Műszaki Tudományos Közlemények 10. (2019). https://eda.eme.ro/handle/10598/31161

[7] The 26th Mediterranean Conference on Control and Automation, MED 2018 Process automation challenge. 2018.

http://www.med-control.org/med2018/wp-content/uploads/2018/02/MED2018_Process_automation_challenge_task_details.pdf (letöltve: 2018. február 27.).

[8] László D., Katalin Gy., András K.: Modell alapú prediktív irányítási algoritmus, állapotfüggő Riccati-egyenlet, illetve véges horizontú $D L Q R$ algoritmusok összehasonlítása. In: A XV. Műszaki Tudományos Ülésszak előadásai. Kolozsvár, Románia, Müszaki Tudományos Közlemények 2. (2015) 61-74. http://hdl.handle.net/10598/28549 